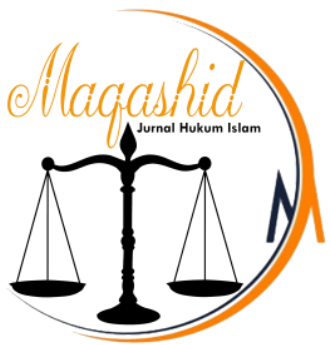

Al-Ahwal Al-Syakhsiyah, IAI Al-Qolam

Maqashid (2020) Vol.3. No.l: 77-94

http://ejournal.alqolam.ac.id/index.php/maqashid

p-ISSN : 2613-9758, e-ISSN : 2685-4619

(c) Maqashid 2020

\title{
PANDANGAN MASYARAKAT TENTANG PARAMETER KEDEWASAAN PEREMPUAN DALAM PERKAWINAN PERSPEKTIF MASLAHAH AL- MURSALAH
}

(Studi Kasus di Kecamatan Wonodadi Kabupaten Blitar)

\section{A'YUNINA MAHANANI}

Dosen Pendidikan Bahasa Arab Universitas Muhammadiyah Sidoarjo dan Ma'had Umar Bin alkhattab Putri Sidoarjo

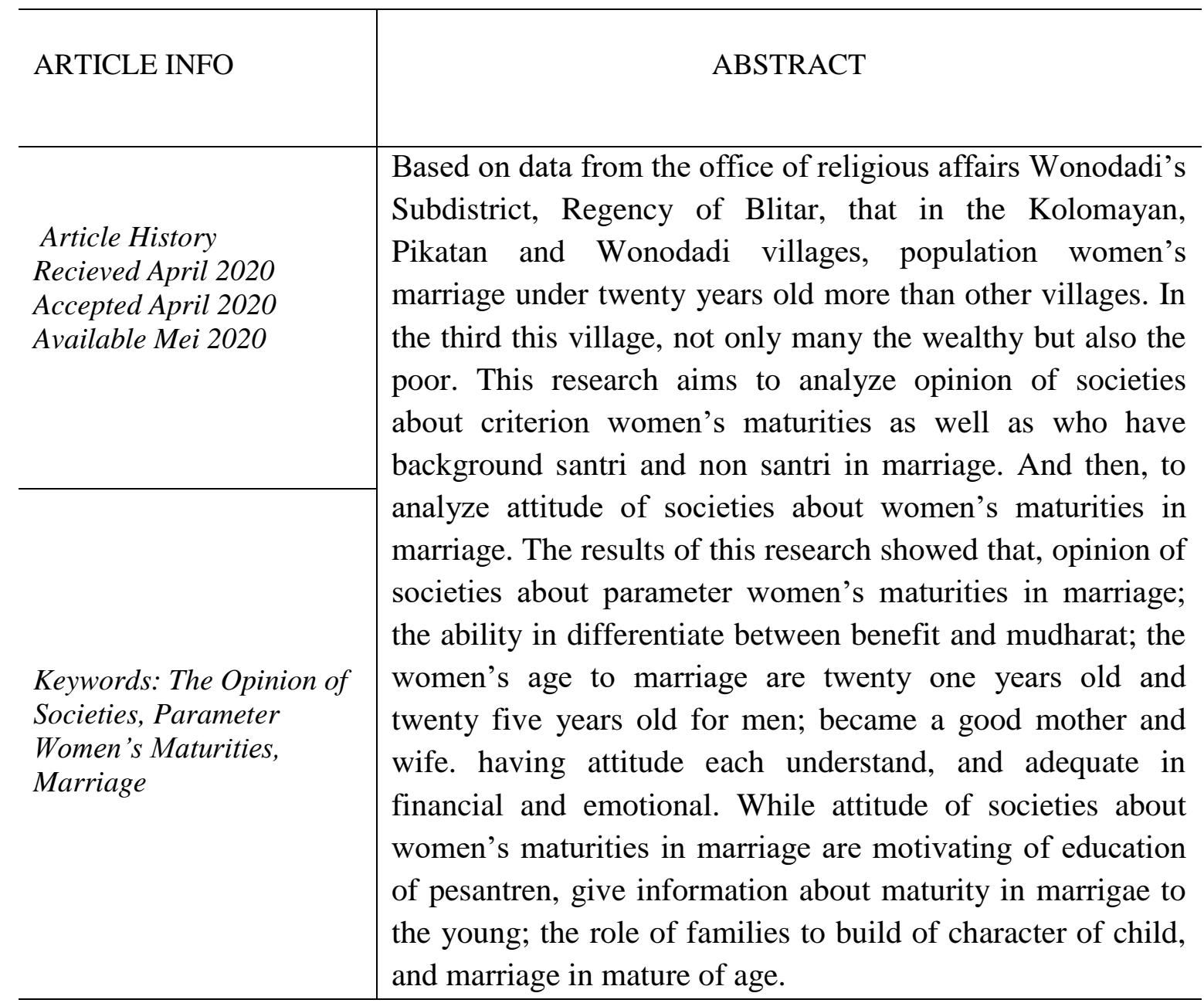




\section{A. Pendahuluan}

Perempuan mempunyai peran ganda dalam suatu keluarga yaitu berperan sebagai istri sekaligus ibu dari anak-anaknya. Bentuk dan sistem yang diterapkan dalam keluarga, wanita mempunyai andil sangat besar. Keluarga sakinah, mawaddah dan rahmah adalah sistem keluarga yang selalu diinginkan setiap pasangan. Oleh karena itu setiap pasangan suami istri selalu berupaya untuk mewujudkannya sesuai cara masingmasing, seperti yang terjadi di kecamatan Wonodadi Kabupaten Blitar.

Menurut data dari Kantor Urusan Agama Kecamatan Wonodadi Kabupaten Blitar bahwa di ketiga desa di Kecamatan Wonodadi, yaitu Desa Kolomayan, Pikatan, dan Wonodadi, populasi pernikahan berdasarkan umur wanita di bawah 20 tahun sangat banyak di banding desa-desa lainnya. Setiap bulannya berkisar 5 hingga 10 orang yang melangsungkan pernikahan di bawah umur 20 tahun. ${ }^{1}$ Di ketiga desa ini golongan masyarakat bermacam-macam, mulai dari kalangan mapan secara ekonomi dan mapan secara akademik hingga ke kalangan yang kurang mampu secara ekonomi dan akademik. $^{2}$

Beberapa dari pasangan suami istri yang menikah di usia muda memiliki berbagai macam alasan sebelum melangsungkan pernikahan. Beberapa di antara mereka dikarenakan faktor adat keluarga, faktor ekonomi yang kurang mapan dari orang tua sehingga untuk melanjutkan ke pendidikan yang lebih tinggi mereka tidak mampu membiayainya, hingga faktor hamil di luar nikah yang mengharuskan mereka menikah di usia yang sangat muda.

Secara geografis Kecamatan Wonodadi adalah kecamatan perbatasan antara Kabupaten Tulungagung dan Kabupaten Blitar. Di kecamatan ini keadaan sosiologis masyarakat sangat beragam, sebagian ada yang berlatar pendidikan pesantren dikarenakan sebagian masyarakat peduli dengan pendidikan agama. Di kecamatan ini banyak berdiri pondok pesantren seperti Abul Faidl, Al-Kamal, Darul Huda, dan Manhajul Qurra'. Sebagian masyarakat ada juga yang lebih condong ke pendidikan umum atau non pesantren. ${ }^{3}$ Hal ini menarik dan penting bagi penulis untuk melalukan penelitian di daerah tersebut. Karena, di samping kasus setiap bulannya cukup untuk dilakukan penelitian, masyarakatnya sudah mewakili dari yang berlatar belakang pesantren dan non pesantren, yang memiliki strategi pembentukan keluarga sakinah yang berbeda-beda sesuai latar belakang masing-masing.

Menurut Ibu Diyah salah satu pegawai kantor PLKB (Petugas Lapangan Keluarga Berencana), bahwa perempuan yang matang secara umur sangat berpengaruh dalam membina sebuah keluarga, apalagi disertai dengan pendidikan yang memadai. Hal ini

\footnotetext{
${ }^{1}$ Data tertulis merupakan laporan bulanan pernikahan yang terjadi di kecamatan Wonodadi selama 5(Lima) tahun terakhir yang diperoleh dari Kantor Urusan Agama (KUA) pada tanggal 9 Desember 2015.

${ }^{2}$ Penduduk di Kecamatan Wonodadi mayoritas bermata pencaharian sebagai wiraswasta yaitu peternak ayam, pedagang, pegawai negeri dan petani.

${ }^{3}$ Hasil Pengamatan penulis mulai dari tanggal 21Desember 2015 hingga 3 Januari 2016.
} 
diharapkan bisa mengurangi angka perceraian di suatu daerah. ${ }^{4}$ Dapat disimpulkan bahwa pendidikan mempunyai peran yang penting dalam pembentukan sebuah keluarga, karena akan terlihat berbeda antara sebuah keluarga yang berpendidikan dan non pendidikan.

Adanya ikatan perkawinan menjadikan keperibadian suami dan istri menjadi satu. Kedua belah pihak harus merasa saling memiliki dan saling menyatu sehingga kekurangan masing-masing sedapat mungkin ditutupi dengan melihat sisi positif atau kelebihan-kelebihan yang ada pada diri masing-masing. Dengan demikian hubungan kerja sama antara suami dan istri sebagai mitra sejajar dapat diwujudkan dengan jalinan pola sikap dan perilaku sehari-hari, baik dalam kehidupan keluarga maupun kehidupan bermasyarakat.

Menurut pasal 1 dalam Undang-Undang No.1. Tahun 1974 tentang Perkawinan bahwa:

"Perkawinan ialah ikatan lahir bathin antara seorang pria dengan seorang wanita sebagai suami istri dengan tujuan membentuk keluarga (rumah tangga) yang bahagia dan kekal berdasarkan Ketuhanan Yang Maha Esa”.

Untuk mencapai tujuan dari perkawinan tersebut, kedewasaan pisik, kedewasaan berpikir dan kematangan jiwa atau mental bagi pasangan suami istri sangat dibutuhkan. Salah satu hal yang perlu dipertimbangkan oleh seseorang sebelum melangsungkan perkawinan adalah faktor usia. Usia perkawinan merupakan salah satu aspek yang berpengaruh terhadap kematangan atau kedewasaan emosional psikologis, kematangan fisiologis atau jasmani, dan kematangan sosial ekonomi.

Selain faktor usia, pendidikan merupakan salah satu tonggak penting dan mendasar bagi kebahagiaan hidup manusia. Nasib baik atau buruk secara lahir maupun batin seseorang, sebuah keluarga, sebuah bangsa, bahkan seluruh umat manusia, bergantung secara langsung pada bentuk pendidikan mereka. ${ }^{5}$

Penyelesaian permasalahan yang muncul dalam keluarga setiap pasangan memiliki cara yang berbeda. Di samping kematangan psikis suatu pasangan, faktor pendidikan mempunyai peran dan andil penting di dalamnya. Pasangan yang pendidikannya setingkat SD (Sekolah Dasar) dan pasangan yang pendidikannya setingkat SMA (Sekolah Menengah Atas) secara tidak langsung berbeda dalam menyelesaikan suatu masalah. Begitu juga pasangan yang lulusan pondok pesantren dan lulusan non pondok pesantren berbeda dalam menyelesaikan permasalahan keluarga.

Fokus penelitian ini adalah perempuan yang sudah menjalani pernikahan minimal dua tahun ke atas yang ketika mereka menikah berusia 18 tahun ke atas. Dalam Pasal 1 butir 1 Undang-Undang No. 23 Tahun 2002 tentang Perlindungan Anak dinyatakan bahwa; "Anak adalah seseorang yang belum berusia 18 (delapan belas) tahun, termasuk anak yang masih dalam kandungan."

\footnotetext{
${ }^{4}$ Hasil wawancara penulis dengan Ibu Diyah salah satu pegawai kantor PLKB pada hari senin tanggal 4 januari 2016

${ }_{5}^{5}$ Banu Garawiyan, Memahami Gejolak Emosi Anak, (Bogor: Cahaya, 2002), hal 1.
} 
Adapun dalam Undang-Undang No. 1 Tahun 1974 tentang Perkawinan Bab 2 pasal 7 ayat 1 berbunyi: "Perkawinan hanya diizinkan jika pihak pria sudah mencapai umur 19 (sembilan belas) tahun dan pihak wanita sudah mencapai umur 16 (enam belas) tahun". Selanjutnya dalam Peraturan Menteri Agama No. 11 tahun 2007 Tentang Pencatatan Nikah Bab IV pasal 8 yaitu: "Apabila seorang calon suami belum mencapai umur 19 (sembilan belas) tahun dan seorang calon isteri belum mencapai umur 16 (enam belas) tahun, harus mendapat dispensasi dari pengadilan". Pasal-pasal diatas sangat jelas dan tidak ada penafsiran ganda, bahwa usia minimal pernikahan calon suami 19 (sembilan belas) tahun dan calon isteri berusia 16 (enam belas) tahun. Namun itu saja belum cukup, dalam tataran implementasinya masih ada syarat yang harus di tempuh oleh calon pengantin (catin), yakni jika calon suami dan calon istri belum genap berusia 21 (dua puluh satu) tahun maka harus ada ijin dari orang tua atau wali nikah. Hal ini sesuai dengan Peraturan Menteri Agama No. 11 tahun 2007 tentang Pencatatan Nikah Bab IV pasal 7 yaitu: "Apabila seorang calon mempelai belum mencapai umur 21 (dua puluh satu) tahun, harus mendapat ijin tertulis kedua orang tua”. Ijin ini sipatnya wajib, karena usia itu dipandang masih memerlukan bimbingan dan pengawasan orang tua atau wali. Hal ini juga dikuatkan dalam pasal 15 ayat 2 Kompilasi Hukum Islam.

Jika dilihat sebagian pasal pada Undang-Undang No. 1 Tahun 1974 tentang Perkawinan (UUP) dan Undang-Undang No. 23 Tahun 2002 tentang Perlindungan Anak (UUPA) di atas perlu dilakukan elaborasi antara keduanya. Namun dalam penelitian ini penulis menitikberatkan pada tolak ukur kedewasaan perempuan dalam membentuk keluarga sakinah. Oleh karena itu dasar acuan undang-undang yang dipakai adalah undang-undang tentang perlindungan anak.

Uraian Undang-Undang perlindungan anak di atas menunjukkan bahwa batasan usia anak adalah 18 tahun. Jadi perempuan yang belum berusia 18 tahun disebut anakanak dan di atas 18 tahun disebut dewasa. Oleh karena itu, dalam hal pernikahan seorang perempuan seyogyanya sudah dalam tahapan dewasa, karena sangat berpengaruh terhadap kematangan fisik, mental, dan sebagainya.

\section{B. Diskursus tentang Parameter Kedewasaan Perempuan}

Pernikahan merupakan sunnah Rasulullah SAW yang apabila dilaksanakan akan mendapatkan pahala, tetapi jika tidak dilakukan tidak mendapatkan dosa melainkan makruh karena tidak melaksanakan sunnah Rasulullah SAW. ${ }^{6}$

Pernikahan merupakan perbuatan yang disyariatkan Allah SWT, hal ini sesuai dengan firman Allah SWT dalam surat an-Nisa ayat 3 yaitu:

\footnotetext{
${ }^{6}$ Syaikh Kamil Muhammad 'Uwaidah, Fikih Wanita, (Jakarta: Pustaka Al-Kautsar, 1998), hal 375.
} 


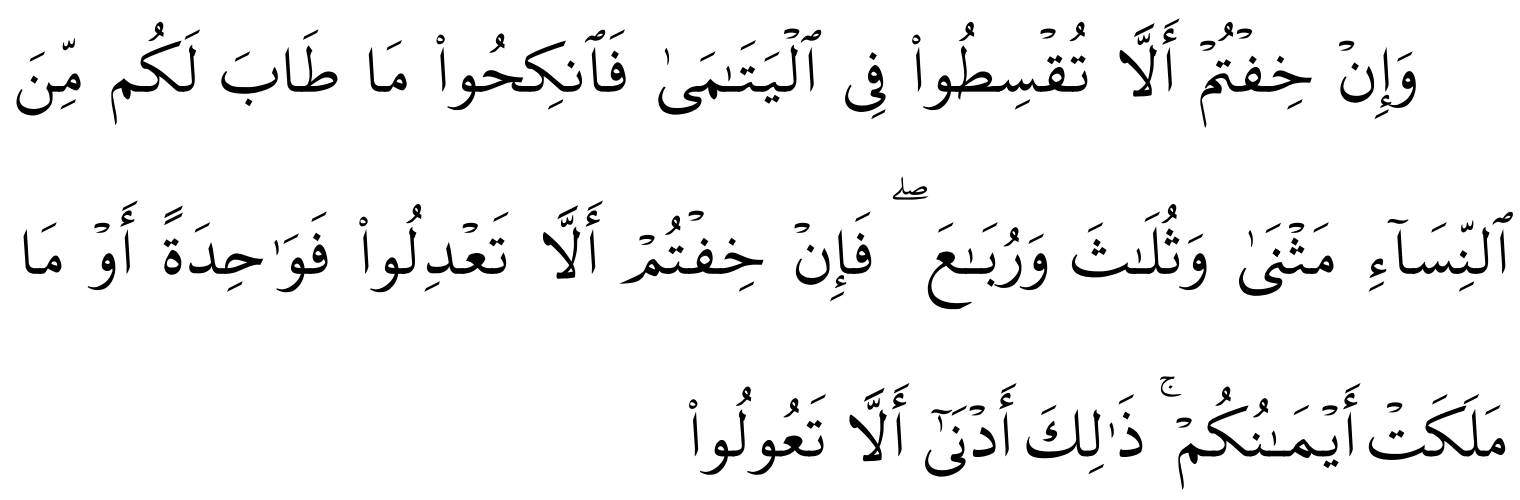

Dan jika kamu takut tidak akan dapat Berlaku adil terhadap (hak-hak) perempuan yang yatim (bilamana kamu mengawininya), Maka kawinilah wanita-wanita (lain) yang kamu senangi : dua, tiga atau empat. kemudian jika kamu takut tidak akan dapat Berlaku adil, Maka (kawinilah) seorang saja, atau budak-budak yang kamu miliki. yang demikian itu adalah lebih dekat kepada tidak berbuat aniaya. ${ }^{7}$

Kematangan psikologis atau sering disebut kematangan berarti kedewasaan yang dapat melakukan tugasnya sebagaimana mestinya. Kematangan sendiri terbagi menjadi beberapa hal, yaitu: kematangan emosi, kematangan sosial, kematangan spiritual atau agama, kematangan fisik, dan kematangan ekonomi yang mana semua jenis kematangan diatas memerlukan proses pembelajaran yang bertahap dan terus-menerus.

Kematangan emosi adalah keadaan dimana suatu individu dapat menerima suatu keadaan atau kondisi dengan memunculkan emosi yang sesuai dengan apa yang terjadi padanya tanpa berlebihan atau meledak-ledak.

Kematangan sosial adalah kemampuan perilaku sebagai kinerja yang menunjukkan kemampuan berpartisipasi dalam lingkungan yang ditunjukan dengan antara lain mampu bekerja sama dalam kelompok, berani menampilkan diri sesuai dengan minatnya, dapat menunjukan sikap berbagi, dapat besikap sesuai norma dengan lingkungan, mampu bersikap simpati dan empati, dapat bersikap ramah, tidak egois, suka meniru perilaku positif lingkungannya, serta dapat memberi kasih sayang kepada orang yang dekat.

Kematangan beragama ialah orang yang memiliki kemandirian spiritual. Artinya, orang yang sudah mampu memfasilitasi standar kebutuhan spiriritualnya tanpa harus tergantung kepada orang lain. Kematangan spiritual ditandai dengan kemampuan seseorang untuk mengendalikan diri dari berbagai keinginan nafsu, misalnya nafsu birahi, nafsu amarah, keinginan untuk menang sendiri (egoisme), berfoya-foya, melakukan riya maupun sombong. Kematangan spiritual juga terlihat di dalam tutur kata yang santun, perilaku yang santun, berfikir lurus, dan berperilaku

\footnotetext{
${ }^{7}$ QS An-Nisa ( 04:03)
} 
tawadhu. Mengutip dari Abdul Aziz Ahyadi, G.W Allport dalam memberikan ciri-ciri kesadaran beragama yang matang ialah sebagai berikut: ${ }^{8}$

1. Diferensiasi yang baik, dalam perkembangan kehidupan kejiwaan, differensiasi berarti semakin bercabang, makin bervariasi, makin kaya dan makin majemuk suatu aspek psikis dimiliki seseorang. Penghayatan hubungan dengan Tuhan makin dirasakan bervariasi dalam berbagai suasana dan nuansa. Apabila melihat keindahan alam ia berusaha menggali dan merasakan tanda-tanda keindahan Tuhan, apabila ia menyaksikan kasih sayang orang tua kepada anaknya dan keikhlasan perawat pasien dan semacamnya, ia dapat merasakan kasih sayang Tuhan. Hasil differensiasi kesadaran beragama yang terpolakan dalam suatu sistem mental adalah mengharapkan akan surga dan keridhaan Tuhan, kecemasan dan ketakutan terhadap api neraka dan siksaan Tuhan, cinta kasih terhadap sesama pemeluk agama serta kebencian terhadap hawa nafsu dan godaan syetan.

2. Motivasi kehidupan beragama yang dinamis, tanda kedua kesadaran beragama yang matang ialah adanya motif kehidupan beragama yang dinamis, bayi yang baru lahir telah memiliki potensial motif-motif kejiwaan dan rohaniah yang akan timbul apabila mencapai fase perkembangan tertentu melalui pengaruh lingkungan. Oleh karena itu untuk menimbulkan motif-motif rohaniah seorang manusia harus dibiasakan dengan kegiatan-kegiatan keagamaan yang pada akhirnya merupakan motif yang berdiri sendiri dan secara konsisten serta dinamis mendorong manusia untuk bertingkah laku keagamaan.

3. Pelaksanaan ajaran agama secara konsisten dan produktif, tanda ketiga dari kematangan beragama terletak pada konsistensi atau keajegan pelaksanaan hidup beragama secara bertanggung jawab dengan mengerjakan perintah agama sesuai kemampuan dan meninggalkan larangan-Nya. Pelaksanaan kehidupan beragama merupakan realisasi penghayatan ke-Tuhanan dan keimanan. Cakupan daripada Ibadah adalah pelaksanaan aturan, hukum, ketentuan, tata cara, perintah, kewajiban, dan larangan dalam hubungannya dengan Tuhan, manusia, masyarakat, dan alam.

4. Pandangan hidup yang komprehensif, kepribadian yang matang ialah dia yang memiliki filsafat hidup (agama) yang utuh dan komprehensif. Manusia memerlukan pegangan agar dapat menentukan pilihan tingkah lakunya secara pasti.

5. Pandangan hidup yang integral, kesadaran beragama yang matang ditandai adanya pegangan hidup yang komprehensif yang dapat mengarahkan dan menyelesaikan berbagai permasalahan hidup. Di samping komprehensif, pandangan dan pegangan hidup harus terintegrasi. Dalam kesadaran beragama, integrasi tercermin pada keutuhan pelaksanaan ajaran agama, yaitu keterpaduan ihsan, iman, dan peribadatan. Pegangan hidup yang komprehensif dan terintegrasi dengan harmonis bukan hanya mampu menghadapi permasalahan hidup empat belas abad yang lalu, akan tetapi

\footnotetext{
${ }^{8}$ Abdul Aziz Ahyadi, Psikologi Agama Kepribadian Muslim Pancasila, (Bandung: Sinar Baru Algensindo, 2001), hal 50-60.
} 
dapat menjadi pegangan bagi manusia yang hidup pada masa kini yang ditandai kepesatan perkembangan sains dan teknologi.

6. Semangat pencarian dan pengabdian kepada Tuhan, ciri lain dari orang yang memiliki kesadaran beragama yang matang ialah adanya semangat mencari kebenaran, keimanan, rasa ke-Tuhanan dan cara-cara terbaik untuk berhubungan dengan manusia dan alam sekitar. Ia selalu menguji keimanannya melalui pengalaman-pengalaman keagamaan sehingga menemukan keyakinan lebih tepat. Ibadahnya juga selalu dievaluasi dan ditingkatkan agar menemukan kenikmatan penghayatan kehadiran Tuhan. Walaupun demikian ia masih merasakan bahwa keimanan dan peribadatannya, belum sebagaiaman mestinya dan belum sempurna.

Kematangan ekonomi adalah dimana seseorang merasa mampu untuk memenuhi kebutuhan-kebutuhan hidupnya dari segi materil secara mandiri dan juga keluarganya.

Dalam Al-Qur'an pada surat An-Nisa' ayat keenam Allah SWT berfirman sebagai berikut: ${ }^{9}$

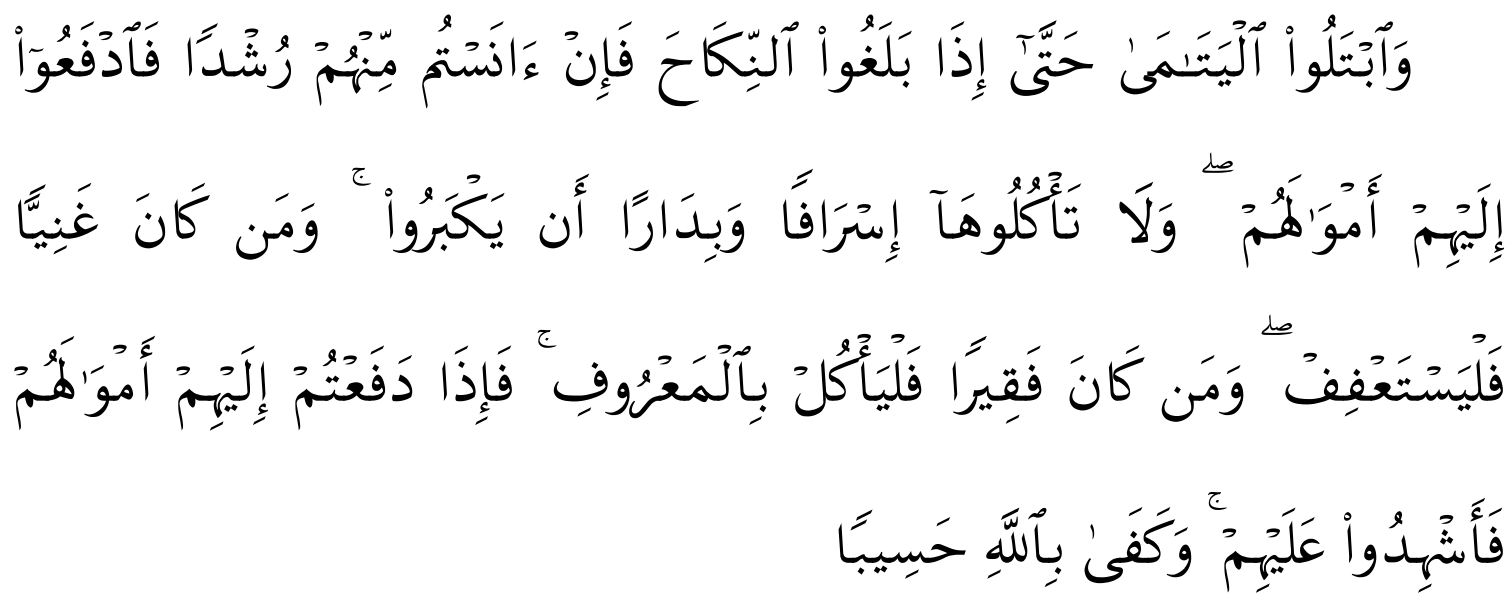

Dan ujilah anak yatim itu sampai mereka cukup umur untuk kawin. Kemudian jika menurut pendapatmu mereka telah cerdas (pandai memelihara harta), maka serahkanlah kepada mereka harta-hartanya. Dan janganlah kamu makan harta anak yatim lebih dari batas kepatutan dan (janganlah kamu) tergesa-gesa (membelanjakannya) sebelum mereka dewasa. Barangsiapa (di antara pemelihara itu) mampu, maka hendaklah ia menahan diri (dari memakan harta anak yatim itu) dan barangsiapa miskin, maka bolehlah ia makan harta itu menurut yang patut. Kemudian apabila kamu menyerahkan harta kepada mereka, maka hendaklah kamu adakan saksi-saksi (tentang penyerahan itu) bagi mereka. Dan cukuplah Allah sebagai Pengawas (atas persaksian itu).

Pada ayat diatas terdapat kata رشدا yang mana para ulama berbeda pendapat di dalam penafsirannya. Menurut Hasan dan Qatadah maksud dari kata tersebut adalah

\footnotetext{
${ }^{9}$ QS An-Nisa' (04:06)
} 
matang secara akal dan agama, adapun menurut Ibn Abbas dan Suddi dan Tsauri adalah matang secara akal dan dapat memelihara harta. ${ }^{10}$ Jika kita lihat dan teliti dari kedua رشدا pendapat diatas, kita mendapati persamaan yaitu kedua-duanya menafsirkan kata dengan kata dewasa atau matang secara akal, yang mana dalam implementasi kehidupan sehari-hari dapat menyelesaikan masalah yang menimpa dirinya secara mandiri tanpa melibatkan orang lain. Oleh karena itu penulis menyimpulkan di dalam perkawinan syarat baligh atau cukup umur saja tidak cukup, akan tetapi juga sangat diperlukan kedewasaan atau kematangan secara akal, sehingga tujuan dari perkawinan untuk mewujudkan keluarga yang sakinah.

\section{Teori Maslahah Al-Mursalah}

\section{Arti Maslahah}

Dari segi bahasa kata maslahah (مصلحة) berasal dari kata shalaha (صلح) yang berarti baik. ${ }^{11}$ Kata Al-Maslahah adalah seperti lafadz Al-Manfa'at, baik artinya ataupun wajan-nya (timbangan kata), yaitu kalimat mashdar yang sama artinya dengan kalimat ash-Shalah, seperti halnya lafazh Al-Manfa'at sama artinya dengan Al-Naf'u. ${ }^{12}$

Maslahah Al-Mursalah terdiri dari dua kata yaitu maslahah dan mursalah. Pengertian maslahah dalam bahasa Arab adalah perbuatan-perbuatan yang mendorong kepada kebaikan manusia. Dalam artinya umum adalah setiap segala sesuatu yang bermanfaat bagi manusia, baik dalam arti menarik atau menghasilkan keuntungan atau kesenangan, atau dalam arti menolak atau menghindarkan seperti menolak kemudaratan atau kerusakan. ${ }^{13}$

Maslahah Al-Mursalah menurut Imam Malik sebagaimana hasil analisis AlSyatibi, adalah suatu maslahah yang sesuai dengan tujuan, prinsip dan dalil-dalil syara yang berfungsi untuk menghilangkan kesempitan, baik yang bersifat dharuriyat (primer) maupun hajjiyat (sekunder).

Menurut Abu Nur Zuhair, Maslahah Al-Mursalah adalah suatu sifat yang sesuai dengan hukum, tapi belum tentu diakui atau tidaknya oleh syara.

Menurut Abu Zahrah, Maslahah Al-Mursalah adalah maslahah yang sesuai dengan maksud pembuat hukum (Allah) secara umum, tapi tidak ada dasar yang secara khusus menjadi bukti diakui atau tidaknya.

\footnotetext{
${ }^{10}$ Abu Abdullah Muhammad bin Ahmad al-Anshori al-Qurthubi, Al-Jami’liahka@m Al-Qur'an, (Kairo: Dar Al-Hadits, 2010) hal 37-38.

${ }^{11}$ Amir Syarifuddin, Ushul Fiqh Jilid II, (Jakarta: Kencana, 2011), hal 345.

${ }^{12}$ Rachmat Syafe'i, Ilmu Ushul Fiqh, (Bandung: Pustaka Setia, 1999), hal 117.

${ }^{13}$ Amir Syarifuddin, Ushul Fiqh Jilid II, hal 345.
} 
Menurut al-Ghazali, Maslahah Al-Mursalah adalah suatu metode istidla@l (mencari dalil) dari nash syara' yang tidak merupakan dalil tambahan terhadap nash syara', tapi ia tidak keluar dari nash syara' ${ }^{14}$

Muhammad Muslehuddin mengartikan Maslahah Al-Mursalah adalah kepentingan bersama yang tidak terbatas, atau kepentingan yang tidak ada ketentuannya. hal ini berangkat dari teori Imam Malik bahwa konsep syari'ah itu ada untuk kepentingan bersama, maka sesuatu yang memberikan kemanfaatan dan mencegah kemudaratan bersama adalah merupakan salah satu sumber syariah. Sumber baru inilah yang dinamakan Maslahah Al-Mursalah. ${ }^{15}$

Menurut istilah ahli ushul, masalah dapat diartikan kemaslahatan yang disyariatkan dalam wujud hukum, dalam rangka menciptakan kemaslahatan, di samping tidak terdapat dalil yang membenarkan dan menyalahkannya. ${ }^{16}$

Dari beberapa definisi tentang Maslahah Al-Mursalah dengan rumusan yang berbeda tersebut dapat disimpulkan bahwa maslahah itu adalah sesuatu yang dipandang baik oleh akal sehat karena mendatangkan kebaikan dan menghindarkan keburukan atau kerusakan bagi manusia, sejalan dengan tujuan syara' dalam menetapkan hukum. ${ }^{17}$

\section{Macam-macam Maslahah}

Maslahah Al-Mursalah ada beberapa macam ditinjau dari beberapa segi, yaitu sebagai berikut: ${ }^{18}$

a. Berdasarkan segi kekuatannya sebagai hujjah dalam menetapkan hukum.

1. Maslahah dharu@ riyah, yaitu kemaslahatan yang berhubungan dengan kebutuhan pokok umat manusia di dunia dan di akhirat. Yang termasuk dalam kemaslahatan ini adalah memelihara agama, memelihara jiwa, memelihara akal, memelihara keturunan dan memelihara harta.

2. Maslahah hajjiyah, yaitu kemaslahatan yang dibutuhkan dalam menyempurnakan kemaslahatan pokok atau mendasar yang sebelumnya berbentuk keringanan untuk mempertahankan dan memelihara kebutuhan dasar manusia. Misalnya dalam bidang ibadah diberi keringanan meringkas shalat (menjama') dan berbuka puasa bagi orang yang musafir dalam bidang muammalah antara lain dibolehkan berburu binatang, melakukan jual beli pesanan.

3. Maslahahtahsi@niyah, yaitu kemaslahatan yang bersifat pelengkap berupa keleluasaan yang dapat melengkapi kemaslahatan sebelumnya. Misalnya,

\footnotetext{
${ }^{14}$ Amir Syarifuddin, Ushul Fiqh Jilid III, hal 119.

${ }^{15}$ Muhammad Muslehuddin, Filsafat Hukum Islam, Terj. Yudian Wahyudi Asmin DKK., (Yogyakarta:

Tiara Wacana Yogya, 1991), hal 127.

${ }^{16}$ Zurifah Nurdin, M. Ag, Ushul Fiqh 1, (

${ }^{17}$ Amir Syarifuddin, Ushul Fiqh Jilid II, hal 347.

${ }^{18}$ Amir Syarifuddin, Ushul Fiqh Jilid III., hal 348-354.
} 
dianjurkan untuk memakan makanan begizi, berpakaian yang bagus dan berbagai jenis cara menghilangkan najis dari badan manusia.

b. Berdasarkan segi perubahan maslahah

1. Maslahahtsa@bitah, yaitu kemaslahatan yang sifatnya tetap tidak berubah sampai akhir zaman. Misalnya berbagai kewajiban ibadah seperti shalat dan lainya.

2. Maslahah mutaghayyrah, yaitu kemaslahatan yang berubah-ubah sesuai dengan perubahan tempat, waktu, dan subyek hukum. Kemaslahatan seperti ini berkaitan dengan permasalahan muamalah dan adat kebiasaan, seperti makan makanan yang berbeda-beda antara daerah yang satu dengan yang lainnya.

\section{Syarat-syarat Maslahah}

Sejalan dengan pengertiannya, maka syarat umum maslahah mursalah adalah ketika tidak ditemukan nash sebagai bahan rujukan. Selanjutnya Imam Malik mengajukan syarat-syarat khususnya yaitu: ${ }^{19}$

a. Adanya persesuaian antara maslahat yang dipandang sebagai sumber dalil yang berdiri sendiri dengan tujuan-tujuan syari'at (maqashid as-syari'ah). Dengan adanya persyaratan ini berarti maslahat tidak boleh menegaskan sumber dalil yang lain, atau bertentangan dengan dalil yang qat'iy. Akan tetapi harus sesuai dengan maslahat yang memang ingin diwujudkan oleh syari'. Misalnya, jenis maslahat itu tidak asing, meskipun tidak diperkuat dengan adanya dalil khas.

b. Maslahat itu harus masuk akal (rationable), mempunyai sifat-sifat yang sesuai dengan pemikiran yang rasional, dimana seandainya diajukan kepada kelompok rasionalis akan dapat diterima.

c. Penggunaan dalil maslahat ini adalah dalam rangka menghilangkan kesulitan yang terjadi (raf'u haraj lazim). Dalam pengertian, seandainya maslahat yang dapat diterima akal itu tidak diambil, niscaya manusia akan mengalami kesulitan. Sebagaimana Allah SWT berfirman dalam surat al-Hajj ayat 78

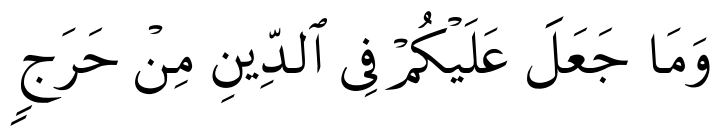

Dia sekali-kali tidak menjadikan untuk kamu dalam agama suatu kesempitan. ${ }^{20}$

Dan Allah SWT berfirman dalam surat al-Baqarah ayat 185

\footnotetext{
${ }^{19}$ Muhammad Abu Zahrah, Ushul Fiqh Terj. Saefullah Ma'shum DKK, Cet II, (Jakarta: PT Pustaka Firdaus, 1994), hal 427.

${ }^{20}$ QS. Al-Hajj (22:78)
} 


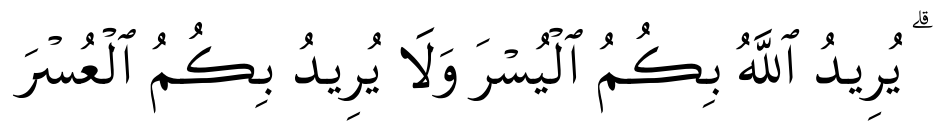

\author{
Allah menghendaki kemudahan bagimu, dan tidak menghendaki kesukaran \\ bagimu. $^{21}$
}

Syarat-syarat di atas adalah syarat-syarat yang masuk akal yang dapat mencegah penggunaan sumber dalil ini (maslahah mursalah) dari hal-hal yang menyimpang dari esensinya, serta mencegah dari menjadikan nash-nash tunduk kepada hukum-hukum yang dipengaruhi hawa nafsu dan syahwat dengan maslahah mursalah.

\title{
4. Objek (Lapangan) Maslahah
}

Lapangan atau ruang lingkup penerapan maslahah mursalah selain yang berlandaskan pada hukum syara secara umum, juga harus diperhatikan adat dan hubungan antara satu manusia dengan yang lainnya, dengan kata lain maslahah mursalah hanya meliputi kemaslahatan yang berhubungan dengan muamalah. ${ }^{22}$ Sebagaimana dalam penelitian ini yang berhubungan langsung dengan kehidupan seharihari, sehingga menurut penulis antara konsep maslahah mursalah yang mengedepankan kemaslahatan dengan permasalahan yang akan diteliti penulis yaitu tentang parameter kedewasaan perempuan dalam perkawinan terdapat kesinambungan.

Sedangkan masalah ibadah bukanlah termasuk dalam lapangan tersebut. Alasannya karena maslahah mursalah didasarkan pada pertimbangan akal tentang baik buruk suatu masalah, sedangkan akal tidak dapat melakukan hal itu untuk masalah ibadah.

Segala bentuk perbuatan ibadah ta'abuddi dan tawqifi, artinya kita hanya mengikuti secara apa adanya sesuai dengan petunjuk syar'i dalam nash, dan akan sama sekali tidak dapat mengetahui kenapa demikian. Misalnya mengenai shalat dhuhur empat rakaat dan dilakukan setelah tergelincir matahari, tidak dapat dinilai akal apakah itu baik atau buruk.

Penerapan maslahah mursalah sebagai metode ijtihad, jumhur ulama sepakat dalam menggunakannya sebagai dalil. Ia digunakan karena adanya petunjuk syara' yang mengakuinya, baik secara langsung maupun tidak langsung. Karena sebagaimana disebutkan di atas bahwa diamalkannya maslahah itu oleh jumhur ulama adalah karena adanya dukungan syar'i, dalam arti lain digunakannya maslahah ini bukan karena semata ia adalah maslahah, tetapi karena adanya dalil syara' yang mendukungnya. ${ }^{23}$

Masalah penentuan usia dalam Undang-Undang Perkawinan maupun dalam Kompilasi, memang bersifat ijtihadiyah, sebagai usaha pembaruan pemikiran fikih yang dirumuskan ulama terdahulu. Maka dari itu, karena sifatnya yang ijtihady, yang

\footnotetext{
${ }^{21}$ QS. Al-Baqarah (02:185)

${ }^{22}$ Rachmat Syafe'i, Ilmu Ushul Fiqh, hal 121.

${ }^{23}$ Amir Syarifuddin, Ushul Fiqh Jilid II, hal 357.
} 
kebenarannya relatif, ketentuan tersebut tidak bersifat kaku. ${ }^{24}$ Artinya, apabila karena sesuatu dan lain hal perkawinan dari mereka yang usianya di bawah 21 (dua puluh satu) tahun atau sekurang-kurangnya 19 (sembilan belas) tahun untuk pria dan 16 (enam belas) tahun untuk perempuan, undang-undang tetap memberi jalan keluar, yaitu sesuai pasal 6 ayat (2) yang mana jika seseorang belum mencapai umur 21 (dua puluh satu) tahun harus mendapat izin kedua orang tua, dan jika kurang dari 19 (sembilan belas) tahun perlu perizinan dari pengadilan, hal ini dikuatkan pasal 15 ayat (2) Kompilasi Hukum Islam.

\section{Gambaran Lokasi Penelitian}

Kecamatan Wonodadi merupakan bagian wilayah Kabupaten Blitar. Luas wilayah Kecamatan Wonodadi 2,54 persen dari luas Kabupaten Blitar atau seluas 40,35 Km2. Kecamatan ini terletak di bagian utara Kabupaten Blitar yang memiliki struktur tanah yang subur karena dialiri Sungai Temas Lama sepanjang 17,5 Km dan Sungai Kajar.

Batas-batas wilayah Kecamatan Wonodadi, sebelah utara berbatasan dengan Kabupaten Kediri dan Kecamatan Udanawu Kabupaten Blitar, sebelah timur berbatasan dengan Kecamatan Srengat Kabupaten Blitar, sebelah selatan dan barat berbatasan langsung dengan Kabupaten Tulungagung.

Kecamatan Wonodadi terbagi menjadi 11 (sebelas) desa, yaitu: 1) Kunir 2) Gandekan 3) Wonodadi 4) Kolomayan 5) Pikatan 6) Tawangrejo 7) Kebonagung 8) Kaliboto 9) Rejosari 10) Salam 11) Jaten. ${ }^{25}$

\section{Desa Wonodadi}

Letak Desa Wonodadi berada di antara empat desa lain yang juga masih termasuk dalam wilayah Kecamatan Wonodadi Kabupaten Blitar. Adapun batas desa tersebut adalah: 1) Sebelah Barat berbatasan dengan Desa Kaliboto Kecamatan Wonodadi. 2) Sebelah Timur berbatasan dengan Desa Pikatan Kecamatan Wonodadi. 3) Sebelah Selatan berbatasan dengan Desa Gandekan Kecamatan Wonodadi. 4) Sebelah Utara berbatasan dengan Desa Tawangrejo Kecamatan Wonodadi.

Jarak desa ini ke ibu kota Kecamatan kurang lebih satu kilometer dengan waktu tempuh 15 (lima belas) menit. Adapun jarak tempuh ke ibu kota Kabupaten kurang lebih 25 (dua puluh lima) kilometer dengan waktu tempuh 45 (empat puluh lima) menit.

Desa Wonodadi ini terdiri dari empat dusun, yaitu sebagai berikut:

1) Dusun Wonodadi 2) Dusun Gambar 3) Dusun Bakalan 4) Dusun Seduri ${ }^{26}$

\footnotetext{
${ }^{24}$ Ahmad Rofiq, Hukum Perdata Islam Di Indonesia, (Depok: PT Rajagrafindo Persada, 2015), hal 60.

${ }^{25}$ www.blitarkab.go.id. Diakses pada tanggal 10 Februari 2017

${ }^{26}$ www.wonodadi.desa.id. Diakses pada tanggal 10 Februari 2017
} 


\section{Desa Pikatan}

Desa Pikatan mempunyai wilayah 595.535 hektar. Letak wilayah yang terdapat pada dataran tanah yang subur, secara geografis terdiri dari empat dusun, yaitu: Dusun Pikatan, Dusun Plosokembang, Dusun Gendis, Dusun Karangtengah. Karena tanah di Desa Pikatan secara umum sangat subur, maka rakyat Desa Pikatan sebagian besar menggantungkan hidupnya di bidang pertanian dan peternakan. Desa Pikatan merupakan salah satu desa yang tergabung dalam wilayah Kecamatan Wonodadi dan terletak di jantung kota Kecamatan Wonodadi sehingga Desa Pikatan termasuk dalam kawasan kota Kecamatan Wonodadi yang sangat strategis. Desa Pikatan adalah salah satu desa yang menghubungkan jalur lalu lintas ekonomi yang padat yang selalu dilewati masyarakat ketika akan membawa barang dagangan menuju Kota Blitar, Kota Tulungagung dan Kediri sehingga secara tidak langsung berdampak secara ekonomi yang baik bagi masyarakatnya. Adapun jarak ke Kabupaten Blitar kurang lebih 30 (tiga puluh )Km, sedangkan ketinggian tempat Desa Pikatan berada $300 \mathrm{M}$ di atas permukaan laut.

Karena Desa Pikatan merupakan salah satu desa kuno yang memiliki peranan penting dalam berbagai bidang politik, ekonomi, hukum, budaya, dan pertahanan keamanan pada masa lampau, masyarakatnyapun juga memiliki karakter yang patriotis dalam perjuangan terhadap Kerajaan juga sangat besar pada masa lalu, tentunya nilainilai luhur tersebut melekat dan diwarisi masyarakat Desa Pikatan pada masa sekarang. ${ }^{27}$

\section{Desa Kolomayan}

Desa Kolomayan memiliki luas tanah 497.035 hektar yang berupa dataran yang subur, hal ini menunjukkan bahwa mayoritas penduduk Desa Kolomayan bermata pencaharian sebagai petani dan peternak. Jumlah penduduk desa ini sebanyak 7.942 jiwa. Batasan wilayah Desa Kolomayan sebelah timur berbatasan dengan Desa Dermojayan Kecamatan Srengat, sebelah utara berbatasan dengan Desa Ringin Anom Kecamatan Udanawu, sebelah selatan berbatasan dengan Desa Kunir Kecamatan Wonodadi, dan sebelah barat berbatasan dengan Desa Pikatan. Jarak antara desa ini dengan Ibu Kota Kecamatan lumayan dekat sekitar empat kilometer, adapun jarak tempuh ke Ibu Kota Kabupaten lumayan jauh sekitar duapuluh kilometer karena Kecamatan Wonodadi ini merupakan kecamatan terakhir sebelum memasuki Kabupaten Tulungagung, tepatnya di ujung barat Kabupaten Blitar. Mayoritas penduduk Desa Kolomayan yang bermata pencaharian sebagai petani, mereka menanami lahannya dengan tanaman jagung dan padi. $^{28}$

\footnotetext{
${ }^{27}$ www.pikatan.desa.id. Diakses pada tanggal 10 Februari 2017

${ }^{28}$ Buku Profil Desa Kolomayan
} 


\section{E. Pandangan Masyarakat tentang Parameter Kedewasaan Perempuan dalam Perkawinan}

\section{Mampu membedakan antara manfaat dan madharat}

Maksud dari kata manfaat sama seperti kata maslahat, yaitu berarti baik. Sebagaimana yang disebutkan di bab terdahulu bahwa pengertian dari kata manfaat atau maslahat dalam bahasa arab adalah perbuatan-perbuatan yang mendorong kepada kebaikan manusia. ${ }^{29}$ Artinya sesuatu yang dipandang baik oleh akal sehat karena mendatangkan kebaikan dan menghindarkan keburukan atau kerusakan bagi manusia, sejalan dengan tujuan syara' dalam menetapkan suatu hukum.

Adapun kata madharat pengertiannya kebalikan dari kata manfaat, yaitu segala sesuatu yang dipandang tidak baik oleh akal sehat karena mendatangkan keburukan dan menghindarkan dari suatu kebaikan dan tidak sejalan dengan tujuan syara' dalam menetapkan hukum.

Dewasa dalam hal ini bukan dilihat dari segi umur, melainkan selama dia mampu dan bisa membedakan segala perbuatan yang mengandung manfaat dan madharat, maka dia sudah memiliki sifat dewasa. Dalam perkawinan, umur bukan satu-satunya jaminan hidup bahagia. Dalam penentuan usia dalam undang-undang perkawinan maupun dalam kompilasi, memang bersifat ijtihadiyah, sebagai usaha pembaruan pemikiran fikih yang dirumuskan ulama terdahulu. Maka dari itu, karena sifatnya yang ijtihady, yang kebenarannya relatif, ketentuan tersebut tidak bersifat kaku. ${ }^{30}$ Artinya, apabila karena sesuatu dan lain hal perkawinan dari mereka yang usianya di bawah 21 (dua puluh satu) tahun atau sekurang-kurangnya 19 (sembilan belas) tahun untuk pria dan 16 (enam belas) tahun untuk perempuan, undang-undang tetap memberi jalan keluar, yaitu sesuai pasal 6 ayat (2) yang mana jika seseorang belum mencapai umur 21 (dua puluh satu) tahun harus mendapat izin kedua orang tua, dan jika kurang dari 19 (sembilan belas) tahun perlu perizinan dari pengadilan, hal ini dikuatkan pasal 15 ayat (2) Kompilasi Hukum Islam. Oleh karena itu sah-sah saja jika perempuan mau menikah di usianya yang masih muda yaitu umur 16 (enam belas) tahun, karena dari segi undang-undang perkawinan sudah melegalkan, dengan syarat sudah memiliki kecakapan dalam membedakan segala perbuatan yang mengandung manfaat maupun madharat. Dalam hal ini sesuai dengan kaidah fiqh yaitu,

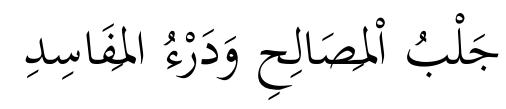

Meraih kemaslahatan dan menolak kemafsadatan. ${ }^{31}$

\footnotetext{
${ }^{29}$ Amir, Ilmu Ushul Fiqh Jilid II, hal 345.

${ }^{30}$ Ahmad Rofiq, Hukum Perdata Islam Di Indonesia, (Depok: PT Rajagrafindo Persada, 2015), hal 60.

${ }^{31}$ Abdul Aziz Muhammad Azzam, al-Qawa@id al-Fiqhiyyah, (Kairo: Da@r al-Hadi@ts, 2005), hal 145.
} 
Dalam kaidah ini bisa diambil kesimpulan bahwa, seluruh maslahat yang diperintahkan oleh syari'at dan seluruh yang mengandung mafsadah atau madharat dilarang oleh syari'at. Adapun kemaslahatan dilihat dari segi syariah dibagi menjadi tiga, ada yang wajib dilaksanakan, ada yang sunnah melaksanakannya, dan ada pula yang mubah melaksanakannya. Demikian pula mafsadah, ada yang haram melaksanakannya, dan ada yang makruh melaksanakannya. ${ }^{32}$ Sebagaimana permasalahan perkawinan, jika seorang perempuan sudah memenuhi kriteria dewasa yaitu mampu membedakan manfaat dan madharat maka boleh baginya untuk menikah, karena pernikahan adalah suatu hal yang disyari'atkan oleh agama Islam.

\section{Kesiapan Mental, Ekonomi dan Kesehatan}

Hampir dalam setiap bidang kehidupan, kedewasaan menjadi ukuran tanggung jawab dari sebuah perbuatan karena hanya seseorang yang telah dewasa saja yang perbuatannya dianggap dapat dipertanggung jawabkan secara sempurna. ${ }^{33}$ Dalam perihal perkawinan, sikap tanggung jawab tiap-tiap pasangan menjadi hal yang sangat penting dalam mewujudkan keluarga yang bahagia, ketika suami bisa memenuhi seluruh tanggung jawabnya terhadap istri, begitu pula sebaliknya ketika istri bisa memenuhi seluruh tanggung jawab terhadap suami, maka secara tidak langsung mereka bisa mewujudkan keluarga yang bahagia. Sebagai contoh seorang suami yang bisa memenuhi segala tanggung jawabnya terhadap istri termasuk kebutuhan lahir seperti kebutuhan materi atau ekonomi, ketika sang suami bisa mencukupi nafkah sang istri maka hal ini bisa meminimalisir sebuah pertengkaran. Oleh karena itu dalam perkawinan dewasa atau matang secara ekonomi sangat diperlukan untuk mewujudkan keluarga yang harmonis. Di sisi lain kebutuhan batin yang harus dipenuhi sang suami terhadap istri, sebagai contoh yaitu suami adalah sebagai panutan (uswatun hasanah) bagi istrinya dari segi perilaku dan juga agama, maka dewasa atau matang secara psikologi, sosial, dan agama juga merupakan aspek penting dalam sebuah perkawinan.

Tidak hanya suami saja yang harus mempunyai sifat dewasa atau matang dari berbagai aspek, namun seorang istri juga mempunyai kewajiban tersebut, karena seorang perempuan dalam keluarga mempunyai peran ganda sebagai istri dan seorang ibu. Terlebih tugas seorang ibu sangatlah berat salah satunya yaitu mendidik anak yang mana baik buruknya seorang anak faktor yang mempengaruhi adalah didikan seorang ibu.

\footnotetext{
${ }^{32}$ Ahmad Sudirman Abbas, Qawaid Fiqhiyyah dalam Perspektif Fiqh, (Jakarta: Radar Jaya Offset, 2004), hal 125-130.

33 Ibid
} 


\section{Menjadi Istri dan Ibu yang Baik}

Kewajiban istri dalam undang-undang perkawinan pasal 34 diatur secara garis besar pada ayat (2), dalam Kompilasi diatur secara lebih rinci dalam pasal 83 dan $84 .{ }^{34}$ Pasal 83

a. Kewajiban utama bagi seorang istri ialah berbakti lahir dan batin kepada suami di dalam batas-batas yang dibenarkanoleh hukum Islam.

b. Istri menyelenggarakan dan mengatur keperluan rumah tangga sehari-hari dengan sebaik-baiknya.

Pasal 84

a. Istri dapat dianggap nusyuz jika ia tidak mau melaksanakan kewajiban-kewajiban sebagaimana dimaksud dalam Pasal 83 ayat (1) kecuali dengan alasan yang sah.

b. Selama istri dalam nusyuz, kewajiban suami terhadap istrinya tersebut pada Pasal 80 ayat (4) huruf a dan b tidak berlaku kecuali hal-hal untuk kepentingan anaknya.

c. Kewajiban suami tersebut pada ayat (2) di atas berlaku kembali sesudah istri tidak nusyuz.

d. Ketentuan tentang ada atau tidak adanya nusyuz dari istri harus didasarkan atas bukti yang sah.

Al-Qur'an telah memberi peringatan bahwa perempuan-perempuan yang saleh, ialah yang taat kepada Allah lagi memelihara diri di balik pembelakangan suaminya. Istri yang shalihah adalah istri yang meskipun memiliki hak dan kewajiban yang seimbang dengan suaminya, kalaupun harus bekerja dia tidak melupakan tugas, peran, dan fungsinya sebagai ibu rumah tangga bagi suami dan anak-anaknya.

Selain sebagai ibu, perempuan juga menjadi ibu bagi anak-anaknya dalam kehidupan rumah tangga. Setiap orang tua yang memiliki anak selalu ingin memelihara, membesarkan, dan mendidiknya. Seorang ibu yang melahirkan anak tanpa ayah pun memiliki naluri untuk memelihara, membesarkan, dan mendidiknya. Orang tua dan anak dalam suatu keluarga memiliki kedudukan yang berbeda. Dalam pandangan orang tua, anak adalah buah hati dan tumpuan di masa depan yang harus dipelihara dan dididik. ${ }^{35}$

Tanggung jawab orang tua terhadap anaknya tampil dalam bentuk yang bermacammacam. Secara garsi besar, bila dibutiri, maka tanggung jawab orang tua terhadap anaknya adalah bergembira menyambut kelahiran anak, memberi nama yang baik, memperlakukan dengan lembut dan kasih sayang, menanamkan rasa cinta sesama anak, memberikan pendidikan akhlak, menanamkan akidah tauhid, melatih anak mengerjakan sholat, berlaku adil, memperhatikan teman anak, menghormati anak, memberi hiburan, mencegah perbuatan bebas, menjauhkan anak dari hal-hal porno (baik pornoaksi maupun pornografi), menempatkan dalam lingkungan yang baik, memperkenalkan kerabat kepada anak, mendidik bertetangga dan bermasyarakat. Dari uraian di atas dapat ditarik

\footnotetext{
${ }^{34}$ Ahmad Rofiq, Hukum Perdata,,,, hal 153.

${ }^{35}$ Syaiful Bahri, Pola Komunikasi, hal 27-28.
} 
kesimpulan bahwa tanggung jawab orang tua terhadap anak meliputi: pendidikan iman, pendidikan moral, pendidikan fisik, pendidikan rasio atau akal, pendidikan kejiwaan, pendidikan sosial, dan pendidikan seksual. ${ }^{36}$

Dalam hal pendidikan, maka orang tua adalah pendidik pertama dan utama dalam keluarga. Bagi seorang anak, orang tua adalah model yang harus ditiru dan diteladani, apalagi seorang ibu yang dalam kesehariannya lebih banyak waktu kebersamaan dengan anak dibanding dengan ayah. Oleh karena itu sebagai orang tua harus memberikan contoh yang baik terhadap anak.

Akhirnya, apa pun alasannya, mendidik anak adalah tanggung jawab orang tua dalam keluarga. Oleh karena itu, sesibuk apa pun pekerjaan yang harus diselesaikan, meluangkan waktu demi pendidikan anak adalah lebih baik. Orang tua yang bijaksana adalah orang tua yang lebih mendahulukan pendidikan anak daripada mengurusi pekerjaan siang dan malam. ${ }^{37}$

\section{F. Kesimpulan}

Dari paparan di atas, dapat penulis simpulkan bahwa pandangan masyarakat tentang parameter kedewasaan perempuan dalam perkawinan adalah sebagai berikut: a) Dewasa adalah kemampuan untuk membedakan antara manfaat dan mudhorot. b) Dewasa terletak pada usia matang yaitu pada perempuan usia 21 (dua puluh satu) tahun, sedangkan laki-laki umur 25 (dua puluh lima) tahun. c) Dewasa adalah bagaimana menjadi ibu dan istri yang baik. d) Mempunyai sikap saling mengerti dan memahami antar pasangan. e) Matang dari segi finansial, emosional dan mental.

\footnotetext{
${ }^{36}$ Ibid.

${ }^{37}$ Syaiful Bahri, Pola Komunikasi, hal 31.
} 


\section{DAFTAR PUSTAKA}

Abu Zahrah, Muhammad, 1994, Ushul Fiqh Terj. Saefullah Ma'shum DKK, Cet II, Jakarta: PT Pustaka Firdaus.

Abdullah Muhammad bin Ahmad al-Anshori al-Qurthubi, Abu, 2010, Al-Jami' liahka@m Al-Qur'an Juz 3, Kairo: Dar Al-Hadits.

Aziz Ahyadi, Abdul, 2001, Psikologi Agama Kepribadian Muslim Pancasila, Bandung: Sinar Baru Algensindo.

Aziz Muhammad Azzam, Abdul, 2005, al-Qawa@id al-Fiqhiyyah, Kairo: Da@r al-Hadi@ts.

Garawiyan, Banu, 2002, Memahami Gejolak Emosi Anak, Bogor: Cahaya.

Kamil Muhammad 'Uwaidah, Syaikh, 1998, Fikih Wanita, Jakarta: Pustaka AlKautsar.

Muslehuddin, Muhammad, Filsafat Hukum Islam, Terj. Yudian Wahyudi Asmin $D K K$., Yogyakarta: Tiara Wacana Yogya.

Rofiq, Ahmad, 2015, Hukum Perdata Islam Di Indonesia, Depok: PT Rajagrafindo Persada

Syarifuddin, Amir, 2011, Ushul Fiqh Jilid II, Jakarta: Kencana.

Syafe'i, Rachmad, 1999, Ilmu Ushul Fiqh, Bandung: Pustaka Setia.

Sudirman Abbas, Ahmad, 2004, Qawaid Fiqhiyyah dalam Perspektif Fiqh, Jakarta: Radar Jaya Offset.

www.blitarkab.go.id

www.wonodadi.desa.id

$\underline{\text { www.pikatan.desa.id }}$ 